\title{
THE ROLE OF THE GOVERNMENT IN EFFORTS TO CREATE A RESIDENTABLE RESIDENCE IN WEST JAVA PRONVISION
}

\author{
PERAN PEMERINTAH DALAM UPAYA MENCIPTAKAN \\ PERMUKIMAN LAYAK HUNI DI PRONVISI JAWA BARAT
}

\author{
Dewi Sulastri, Aan Radiana \\ Faculty of Sharia and Law, UIN Sunan Gunung Djati Bandung \\ Email: dewisulasti@uinsgd.ac.id
}

\begin{abstract}
The mandate of Article 28H of the 1945 Constitution provides guarantees for every Indonesian citizen to be able to live in a prosperous body and soul, have a proper place to live, have a place to live and have a good and healthy living environment that is imperative that the government needs to pay attention to, in this case. West Java Provincial Settlement Service. The purpose of this research is to emphasize the role of the government in providing and providing facilities and assistance for hospitality and residential areas for the community. The research method used in this research is normative juridical with a sociological or empirical approach. The results showed that the West Java provincial government policy towards alleviating unfit for habitation, has been part of the planning since 2018 as in the 2018-2023 RPJMD. The RPJMD 2018-2023 period is planned for repairs of 100,000 (one thousand units) of routine routes with details of 80,000 units of rural route categories in 18 districts and as many as 20,000 units of urban route categories in 9 cities.
\end{abstract}

Keywords: policy, housing and settlement, alleviation

\begin{abstract}
Amanah Pasal 28H UUD 1945 memberikan jaminan kepada setiap warga Negara Indonesia untuk dapat hidup secara sejahtera lahir dan bathin, bertemapat tinggal secara layak, memiliki tempat tinggal dan mendapatkan lingkungan hidup yang baik dan sehat menjadi suatu keharusan yang perlu untuk diperhatikan oleh pemerintah, dalam hal ini Dinas Permukiman Provinsi Jawa Barat. Tujuan penelitian ini adalah untuk mempertegas peran pemerintah dalam menyediakan dan memberikan kemudahan dan bantuan peruamahan dan kawasan permukiman bagi masyarakat. Metode penelitian yang digunakan dalam penelitian ini adalah yuridis normative dengan pendekatan sosiologis atau empiris. Hasil Penelitian menunjukan bahwa Kebijakan pemerintah Provinsi Jawa Barat terhadap pengentasan rumah tidak layak huni, sudah menjadi bagian perencaan mulai sejak tahun 2018 sebagaimana dalam RPJMD 2018-2023. Kurun waktu RPJMD 2018-2023 direncanakan perbaikan terhadap 100.000 (seratus ribu unit) rutilahu dengan perincian sebaganyak 80.000 unit kategori rutilahu perdesaan di 18 kabupaten dan sebanyak 20.000 unit kategori rutilahu perkotaan yang berada di 9 kota.
\end{abstract}

Kata-Kata Kunci: kebijakan, perumahan dan permukiman, pengentasan 


\section{INTRODUCTION}

The guarantee for every citizen to live in physical and spiritual prosperity, have a place to live and get a good and healthy living environment is regulated in Article $28 \mathrm{H}$ of the Constitution of the Republic of Indonesia. Regional government based on the principle of regional autonomy has a duty to realize these ideals and is relevant to the regulation and implementation of proper housing and settlements by placing emphasis on the stages of development, maintenance and repair, prevention and quality improvement of housing and slum settlements, provision of land and funding. as well as communities who have many roles in the alleviation processhis.

Government as mandated by Law No. 1 of 2011 concerning Housing and Settlement Areas, "it is necessary to provide and provide facilities and assistance for housing and settlement areas for the community through the implementation of area-based housing and settlement areas and community self-reliance so that they form a functional unit in the form of physical spatial planning, economic life, and socio-culture that is able to ensure environmental sustainability in line with the spirit of democracy, regional autonomy, and openness in the order of life in society, nation and state "(Ministry of Housing of the Republic of Indonesia, 2011).

One form of concrete steps taken by the government to create a just and prosperous society is to carry out development. The development is carried out in a multidimensional manner based on the existence of harmony, harmony and balance in various sub systems. Conceptually, the existing pressure point on quality human resources must be the main force in terms of increasing development development.

In Indonesia, it can be seen that there are still many residents who live not yet in the proper category and it seems that it is difficult to fulfill them by relying on many uncertain livelihoods. The existing affirmation is based on PP. 38 of 2007 concerning the Division of Government Affairs that Housing has been decentralized. This has triggered the development of public expectations in the regions for better quality public services in the housing sector, especially for Low-Income Communities (MBR) who have had difficulties in accessing houses, considering that housing and settlements are very strategic fields and have characteristics. management which is complex, fragmented, and multidimensional in its management is prone to miss coordination between various parties (Siti Aminah, 2018).

In principle, development is a problem related to the public interest which has a high interest to be resolved by the government. It is based on human desire which is always developing and advancing from time to time. The principle of development itself will sometimes conflict with nature in a distant environment that existed before humans were created.

Efforts to fulfill citizens' rights to a decent place to live in a healthy and safe environment, harmonious and orderly, and to ensure certainty of residence, it is necessary to carry out an arrangement of housing to create integration and synergy in the implementation of housing development carried out by the local government, the private sector and the community accordingly with the Regional Spatial Plan (Dewi Putranto Riau).

With regard to the implementation of national development, the scope of dimensions will be very broad including the areas of territory, natural resources, population, ideology, politics, economy, social, culture, and defense and security. Therefore, in the national development process there will be utilization of natural resources, capital resources and human resources. Development activities themselves have had a positive impact on humans. Meanwhile, human life is made easier by several development products. But on the other hand, development often does not take into account its impact on ecological harmony, both harmony in the natural and human environment (Rizki Pryo et al.).

Another problem that often arises in housing management is the tendency for program implementation to be very project-oriented, not flexible according to needs, and the mismatch between government, community and private financing schemes. In addition, the housing problem is seen as too much a physical development process and only part of the infrastructure so that other urgent aspects such as guidance, administration, and technical guidance seem to be neglected. 
For this reason, Law Number 1 of 2011 concerning Housing and Settlement Areas, substantially emphasizes the obligation of local governments to facilitate the construction and acquisition of houses for low-income communities (MBR) in their regions. In this regulation, the government is required to meet the needs of adequate and affordable housing for all levels of society (adequate shelter for all), which at the same time realizes sustainable human settlements through the regulation of housing management patterns as one of the efforts to accelerate development and increase welfare. social community. This also indicates a continuous reform of public services in the housing sectorBungan (Siti Aminah, 2018).

In the context of public policy, Nugroho stated that housing development is part of public policy. The housing development is carried out through political, social, infrastructure and economic policies. The four policies are related to one another.

The West Java Provincial Government, through the Settlement and Housing Agency, has proposed that the regulations related to the implementation of the housing and housing program be revised because of overlapping rules or authorities between the Regional Government and the Central Government. Head of West Java Diskimrum Bambang Rianto gave an explanation after holding a meeting with the Committee II of the Regional Representative Council (DPD) RI, in Bandung, that "There is a difference between Law Number 1 of 2011 and Law Number 23 of 2014 concerning Regional Government. Regarding Rutilahu in Law No. 23/2014 the authority for low-income housing (MBR) houses becomes the central authority. "

Based on 2016 BPS data, the backlog (gap between the number of houses built and the number of houses needed) in West Java reaches 2,479,753 units. In addition, the unequal population concentration causes unbalanced area development, and the low level of fulfillment of adequate and affordable housing needs, especially for low-income groups, has an impact on slum areas in West Java, which according to the provincial authority has an area of 414,319 hectares or as many as 34 areas. . Likewise, houses that are unfit for habitation, which in 2015 reached 284,784 units (West Java Bappeda Public Relations, 2018).

Previous research that has conducted studies with other mechanisms of the context of government policies in an effort to alleviate unfit for habitation and create habitable housing is one of the studies on the Government's Role in Creating Liveable Housing at the Public Works Office of Cipta Karya and Tataruang, Sidoarjo Regency. .

This research study is motivated by the increasing number of housing developments as a result of the increasing population in Sidoarjo Regency. In the housing environment itself, there must be facilities that support daily activities. This is aimed at ensuring the feasibility of the occupied housing so that it can provide a sense of comfort, safety, peace and prosperity for its residents. The results of this study indicate that the role of the government in creating housing that is suitable for habitation is quite good, this is manifested in, among others, the determination of standardization of housing development, supervision and control of housing development and improvement of housing quality. This role is in accordance with the role of the government as a stabilizer, innovator and catalyst. In realizing adequate housing, which has become a supporting factor, among others, the assistance from the government in the form of physical development and the provision of awards and support from competent human resources. The inhibiting factor, lack of human resources. From studies that have been conducted by several researchers, it is necessary to explore and discover the extent of the role of the West Java Provincial government in fulfilling the basic rights of people who are below the poverty line in the West Java province in terms of fulfilling a decent place to live.

\section{RESEARCH METHODS}

The research method will greatly affect the acquisition of the materials needed in the preparation of the research itself, so that it can then be processed and developed optimally in accordance with the scientific method in order to achieve the research objectives formulated. Law Science recognizes two types of research, namely Normative Legal Research and Sociological or Empirical Legal Research (Soerjono Soekanto and Sri Mahmudji, 2003). The research approach taken is a normative juridical approach and empirical juridical approach. The normative juridical approach is an approach to the problem of the method by seeing, analyzing 
and interpreting theoretical matters concerning legal principles in the form of conceptions, statutory regulations, views, legal doctrine and related legal systems. This type of approach emphasizes obtaining information in the form of legal texts relating to the object under study. Meanwhile, the empirical juridical approach is the procedure used to solve research problems by examining secondary data first and then continuing to conduct research on primary data in the field (Soerjono Soekanto and Sri Mamudji. 1985). The use of empirical juridical methods in this study, namely from the results of data collection and discovery of data and information through field studies in government representative institutions, which in this case are the Department of Spatial Planning and Settlements of West Java Province and several Residential Housing Offices in the regency law territory. / city in West Java. Meanwhile, the empirical juridical approach is the procedure used to solve research problems by examining secondary data first and then continuing to conduct research on primary data in the field (Soerjono Soekanto and Sri Mamudji. 1985). The use of empirical juridical methods in this study, namely from the results of data collection and discovery of data and information through field studies in government representative institutions, which in this case are the Department of Spatial Planning and Settlements of West Java Province and several Residential Housing Offices in the regency law territory/city in West Java. Meanwhile, the empirical juridical approach is the procedure used to solve research problems by examining secondary data first and then continuing to conduct research on primary data in the field (Soerjono Soekanto and Sri Mamudji. 1985). The use of empirical juridical methods in this study, namely from the results of data collection and discovery of data and information through field studies in government representative institutions, which in this case are the Department of Spatial Planning and Settlements of West Java Province and several Residential Housing Offices in the regency law territory. / city in West Java.

\section{RESULTS AND DISCUSSION}

The 1945 Constitution of the Republic of Indonesia Article 28H paragraph 1 states that "every person has the right to live in physical and mental well-being, to have a place to live, and to have a good and healthy living environment, and the right to obtain health services". This verse shows that a person has the right to live in a dwelling with a decent environment, which is a basic right that must be guaranteed to be fulfilled by the government with its authority as the administrator of the State.

The alleviation of slum settlements is a challenge that must be faced by district / city governments, because apart from having major problems, on the other hand, it is a pillar of running the city's economy. The government has set handling of housing and slum settlements as a national target outlined in the 2015-2019 National Medium Term Development Plan (RPJMN). PJMN 2015-2019 states that one of the targets of residential area development is to achieve the alleviation of slum settlements in urban areas to 0 (zero) hectares by handling 38,431 hectares of slum areas. For this reason, all programs of the Directorate General of Human Settlements (DJCK) of the Ministry of Public Works and Public Housing (Kemen. PUPR) within 5 (five) years focused on creating habitable settlements until the target of 0 ha of slums is achieved without displacing them. Therefore, DJCK initiated the development of a collaboration platform to realize habitable settlements. One of them is the KOTAKU program or the City Without Slums.

Cities Without Slums or what is often abbreviated (KOTAKU) is one of a number of strategic efforts from the General Cipta Karya of the Ministry of Public Works and Public Housing to accelerate the handling of slum settlements in several areas in Indonesia. This includes related to appropriate access to citations to be used by the community.

The 2015-2019 RPJMN plans a policy on settlements which the ministry deems very necessary to be resolved quickly. The Directorate General of Human Settlements is the initiator of development in the form of cooperation / collaboration through Slumless Cities (KOTAKU). There is a principle that this program supports the alleviation of settlements that do not have 
legal status in addition to that and creates proper settlements to be used in carrying out the life of the people.

One of the government programs in the development and development of community-based settlements is the City Without Slum Program (Kotaku). The Urban Poverty Reduction Project (P2KP) 1999-2006 prioritized overcoming the economic crisis by means of increasing the capacity of the community to become actors of development through the formation of community institutions that are representative mangakar and accountable. Meanwhile, the PNPM program launched in 2007-2014 is by helping the urban poor to gain access to benefits from improved environmental quality and good governance. The program achievements contained in the slum city program for the existing 2 (two) periods have clearly wanted to become a common priority in achieving sustainable development.

The most important objectives in the Kotaku program for the Urban Poverty Reduction Project (P2KP) 1999-2006 are the development of democratic community institutions, learning planning and implementation of development, and good governance of a government. Meanwhile, the PNPM Urban program for 2007-2014 is not much different from the previous period, but focuses more on alleviating uninhabitable settlements by the lower classes of society, namely in order to build democratic community institutions, learn planning and implementation of development in the context of poverty reduction.

The Urban Slum Management Program (P2KKP) in 2015 has the goal of achieving better quality of facilities, infrastructure and public utilities in achieving the target of residential area development. The latest program issued by the government is the existence of the Tanap Slum City (Kotaku) program. The objective of this program is in principle to continue the existing program, but the direction of the policy taken is to improve the quality of slum settlements and prevent the emergence of new slums.

Government policy based on Law Number 1 of 2011 concerning Housing and Settlement Areas, as explained that in principle everyone has the right to live in a physical and physical well-being, to have a place to live and get a good and healthy living environment which is a fundamental requirement for every human. This of course occupies a very important role in shaping the character and personality of the nation in order to build Indonesian people who have a complete identity, are independent and productive. The law emphasizes that the State must be present and responsible for its citizens in providing protection through the provision of healthy, safe, harmonious and sustainable housing and residential areas.

The condition of houses is not suitable for habitation in West Java Province, until now it is still quite a lot and almost spread across all districts / cities. In urban areas, houses that are not suitable for habitation are found in urban slum areas, while in rural areas they are scattered mainly in poor rural areas. In reducing the number of houses unfit for habitation in West Java, the West Java Provincial Government has launched the handling of unfit for habitation through a housing improvement program for districts / cities in West Java with a target of 100,000 units during 2013 - 2018.

The West Java Provincial Government has renovated 109,293 of 285,000 houses unfit for habitation by 2018.37 Main Programs and activities of West Java Province (SK. Governor of West Java No. 500/Kep./66-Org /2014) in the Assistant Government, Law and human rights, routine has become one of the programs launched, one of which is by carrying out rehabilitation of 100,000 poor people's homes.

The legal basis that underlies policy making in the implementation of settlement alleviation which underlies the implementation of this uninhabitable house repair, namely:

First, Law Number 28 Year 2002 concerning Buildings (State Gazette of the Republic of Indonesia Year 2002 Number 134; Supplement to State Gazette of the Republic of Indonesia Number 4247); Law Number 1 of 2011 concerning Housing and Settlement Areas (State Gazette of the Republic of Indonesia of 2011 Number 7, Supplement to the State Gazette of the Republic of Indonesia Number 5188). Second, Government Regulation Number 36 of 2005 concerning Implementation Regulations of Law Number 28 of 2002 concerning Buildings (State Gazette of the Republic of Indonesia of 2005 Number 83, Supplement to the State Gazette of the Republic of Indonesia Number 4532); Third, Regulation of the Minister of Public Works Number 29/PRT/M /2006 of 2006 concerning Guidelines for Building Technical Requirements; Fourth, Permenpera 
RI No. 22 /PERMEN/M/2008 concerning Minimum Service Standards (SPM) for Public Housing in Provincial and District/City Areas. Fifth, Regulation of the Minister of Health of the Republic of Indonesia Number: 1077/Menkes/PER/V/2011 concerning Guidelines for Air Conditioning in Home Spaces; Sixth Decree of the Minister of Settlements and Regional Infrastructure Number: 403/KPTS/M/2002 concerning Technical Guidelines for the Construction of Simple Healthy Homes (Healthy Hospitals); The seven Regulations of the Minister of Home Affairs of the Republic of Indonesia Number 32 of 2011, concerning Guidelines for Grants and Social Assistance Sourced from the Regional Revenue and Expenditure Budget (State Gazette of the Republic of Indonesia of 2011 Number 450), as amended by Regulation of the Minister of Home Affairs Number 14 of 2016 regarding the Second Amendment to the Regulation of the Minister of Home Affairs of the Republic of Indonesia Number 32 of 2011, concerning Guidelines for Grants and Social Assistance Sourced from the Regional Revenue and Expenditure Budget. Eighth, West Java Governor Regulation No. 4 of 2017, concerning Amendments to the Regulation of the Governor of West Java Number 34 of 2016 concerning Procedures for Budgeting, Implementation, Administration, Accountability, Reporting and Monitoring and Evaluation of Grants and Social Assistance Expenditures sourced from the West Java Province Regional Revenue and Expenditure Budget. Ninth, West Java Provincial Regulation Number 17 of 2017, concerning the West Java Province Regional Budget for Fiscal Year 2018 Regional Gazette Number 17 dated 29 December 2017; Tenth, West Java Governor Regulation Number 91 of 2017, regarding the Elaboration of the Regional Revenue and Expenditure Budget for West Java Province for Fiscal Year 2018 Regional Gazette Number 91 dated 29 December 2017; Eleventh, Indonesian National Standards (SNI) related to technical planning of house buildings. Twelfth Regulations of the Governor of West Java Number 46 of 2015 concerning Guidelines for the Improvement of Unworthy Houses.

Based on the mandate of Law Number 25 of 2004 concerning the Regional Development Planning System, each Regional Apparatus Organization (OPD) is required to prepare a five-year planning document, namely the OPD Strategic Plan which must refer to and be guided by the Regional Medium-Term Development Plan (RPJMD). The Housing and Settlement Service of West Java Province which was formed based on West Java Provincial Regulation No. 6 he year 2016 concerning the Formation and Composition of Regional Apparatus of West Java Province, is the executor of the construction of the housing and settlement sector in West Java (Strategic Plan Document of the West Java Province Housing and Settlement Office 2018-2023).

Development in the housing and settlement sector which includes the housing sector, as well as settlement infrastructure, residential areas, defense, has a very important role in development in West Java. In its development prior to the establishment of an independent OPD, the construction of settlements and housing was carried out with programs that had a positive impact, but in some cases the implementation of activities and expected results was still not optimal. In addition, the challenges of future development will be more difficult with the growing condition of the community.

The 2013 FDES explains that a population settlement can differ from a small village to a large metropolitan city area. The types of housing built also vary from slum settlements to local development. In addition, it can also be categorized that the growth in population in urban settlements is one of the challenges faced by the population for the physical environment in which the settlement is located (Human Settlement and Environmental Health, 2015).

According to Didin Wahyudin, the policy of the routine program in Arcamanik District, Bandung City has not been fully achieved or in other words it has not helped many people to improve the quality of life / health status of the poor, seen from the lack of improvement in all housing conditions and the provision of facilities and infrastructure. This is because not all locations get the same improvements. However, this program has played a role in reducing the number of houses unfit for habitation. This is due to the fact that the data collection of potential beneficiaries is carried out directly by the kelurahan based on suggestions from the RT/RW, which is then re-verified before the assistance is actually given.

Among the several factors that influence the implementation of policies related to the uninhabitable house improvement program in Arcamanik District, Bandung City is the existence of institutional cooperation both within the government bureaucratic structure or outside the 
government in an integrated manner, such as cooperation in physical programs in terms of house repairs and in economic programs. However, in its implementation, the housing unfit for habitation program can have a positive impact on the accuracy of targeting program recipients. From the research conducted by Didin Wahyudin, in principle, it has illustrated that there is still a need to improve the implementation of the uninhabitable housing program in the city of Bandung.

The West Java Provincial Government through the Department of Settlements and Housing (Diskimrum) has attempted a program in the field of Improving Unworthy Houses for the poor in urban areas as a form of contribution to poverty reduction, especially in West Java Province. So that with the support of house repair assistance unfit for habitation can improve the welfare of the poor and create a healthy and safe home environment (Didin Wahyudin, 2015).

The results of Didin Wahyudin's research, related to the source of funds disbursed, were grant assistance from the West Java Province Regional Income and Expenditure Budget which was a form of love and sense of belonging from the government towards people with low income in the poor category with an uninhabitable house repair program which all directions were for improve community welfare. As quoted by Didin Wahyudin from Hikmat et al, "that policy strategies and community empowerment programs, which are generally focused on empowering local or regional potential, will become a strategy for the future.

The coverage of suitable housing in the West Java region continues to increase from $92.41 \%$ in 2014 to $92.78 \%$ in 2016. Data on the coverage of suitable housing in West Java Province is presented in the table.

Table 1.1

Liveable Housing Coverage in West Java Province 2012-2017

\begin{tabular}{ccccccc}
\hline \multirow{2}{*}{ INDICATOR } & \multicolumn{5}{c}{ YEAR } \\
\cline { 2 - 7 } & 2012 & 2013 & 2014 & 2015 & 2016 & 2017 \\
\hline TARGET COVERAGE & - & - & $92.12-96.69$ & $92.69-98.29$ & $98,80-98-89$ & $98.89-94.48$ \\
HOUSEHOLD WORTH & & & & & \\
\hline REALIZATION OF & - & - & & & \\
DECENT HOME & & & & & & \\
\hline
\end{tabular}

Source: LKPJ West Java Province 2017

The government's policy towards alleviating unfit for habitation has been part of the planning starting in 2018 as in the 2018-2023 RPJMD of West Java Province. In principle, Rutilahu, as in the 2018-2023 RPJMD, is a house that does not meet the building safety requirements and the minimum adequacy of the building area and the health of its occupants. In the 2018-2013 RPJMD period, it is planned to improve 100,000 (one thousand units) of routes with details of 80,000 units of rural route categories in 18 districts and as many as 20,000 units of urban route categories in 9 cities.

Table 1.2

Improvements to Unfit for Living in West Java Province 2013-2018

\begin{tabular}{|c|c|c|c|c|c|c|c|}
\hline \multirow{2}{*}{$\begin{array}{c}\text { Source of } \\
\text { funds }\end{array}$} & \multicolumn{6}{|c|}{ Year } & \multirow{2}{*}{ amount } \\
\hline & 2013 & 2014 & 2015 & 2016 & 2017 & 2018 & \\
\hline \multicolumn{8}{|c|}{ Repair Target } \\
\hline $\begin{array}{l}\text { APBD } \\
\text { Prov }\end{array}$ & 10,000 & 20,000 & 20,000 & 20,000 & 20,000 & 20,000 & 100,000 \\
\hline \multicolumn{8}{|c|}{ Realization of Improvement } \\
\hline $\begin{array}{l}\text { APBD } \\
\text { Prov }\end{array}$ & 10,203 & 15,720 & 2,989 & 653 & 9,956 & 20,000 & 59,521 \\
\hline $\begin{array}{c}\text { State } \\
\text { Budget }\end{array}$ & 26,088 & 20,944 & 9,068 & 8,839 & 8,649 & 9,000 & 82,579 \\
\hline $\begin{array}{c}\text { District / } \\
\text { City }\end{array}$ & - & - & - & - & 13,547 & 22,337 & 35,884 \\
\hline CSR & - & 109 & 328 & 79 & - & - & 516 \\
\hline amount & 36,291 & 36,773 & 12,385 & 9,562 & 32,152 & 51,337 & 178,500 \\
\hline
\end{tabular}

Source: LKPJ West Java Province 2017 
In 2017, 127,163 housing units had been completed and a Rutilahu repair budget was available, sourced from the APBN, APBDP and District / City APBD to repair 51,337 units. If everything is done, up to 2018 there will be repairs as many as 178,500 units. Even though the number of repairs exceeds the number promised by the Governor of West Java, the need for repairs to unfit for habitation is still quite large in West Java. Based on data from TNP2K, there are still around 191,507 uninhabitable housing units that need to be addressed.

The Strategic Plan of the Office of Housing and Settlements of West Java Province 20192023 , as a means and process in order to achieve the vision and mission as well as medium-term goals and objectives, the Housing and Settlement Service which has been established to support the achievement of the 2013 Regional Government Vision and Mission 2018, a strategy is formulated so that it can be realized with systematic steps. The strategy is carried out so that the implementation of development can be created and the division of affairs which becomes the authority and is used as the basis for compiling activity programs for a period of five years.

As mandated by Law Number 25 of 2004 concerning the National Development Planning System Chapter 1 Article 1, there are stages containing efforts to achieve long-term goals. This strategy has a mature plan to achieve a specific goal, where the method is formulated to be effective and based on the available resources.

Based on the existing concept of understanding, a strategy has the following characteristics: 1) Strategy is the position of the vision, mission and objectives to be realized. 2) The strategy contains concrete steps that are effective in accordance with the available resources. 3) The strategy is designed to be measurable in nature so that it facilitates the implementation process. 4) Strategies are formulated to achieve the long-term targets that have been previously set. 5) Strategies are useful to further clarify the direction to be taken, and the strategies formulated should have binding strength so that they can become a reference for all parties involved.

Referring to the criteria of consistency, self-adjustment, value creation, and self-potential, the formulation of a strategy can be said to be good if it is sufficient to respond to all possible conditions, accommodate all expectations and interests of all related groups, do not conflict and / or create conflict. - internal conflict. The decisions that serve as the umbrella for strategy formulation reinforce one another. Avoid various kinds of threats that might arise. Allows to reach various opportunities that exist. A concise strategy formulation, a clear and easy-tounderstand formula for all parties involved. The means and or resources needed for strategy implementation are available or can be obtained, strategy implementation can take place in a sustainable manner.

Related to the strategy and policy direction, it is formulated by considering First, the need for housing and settlement development based on general conditions, coverage and performance of development and settlement services as well as strategic problems and issues for housing and settlement development. Second, the vision for the development of West Java Province as well as missions related to the main tasks and functions of the Housing and Settlement Service. The third is formulation of the objectives and targets of housing and settlement development that have been agreed upon and accompanied by performance indicators for the achievement of the objectives / targets. Fourth, the resources that are owned can be a barrier or a driving force for the realization of the target achievement in housing development and residential areas to be achieved. Sources owned include a) sources of funding owned by the government, b) area of land available for development, c) community readiness, and d) readiness of the implementing apparatus. Fifth, strategies and programs for housing and settlement area development that have existed in various development planning and spatial planning documents and expected achievement targets in housing and settlement area development.

\section{Constraints and Efforts to Alleviate and Create Liveable Homes in West Java Province}

The failure to provide public needs has not been reached by the lower class. The problems that arise in the development and alleviation of slum areas include: First, housing prices are not affordable for low-income groups (MBR) and under MBR. Second, the issue of providing land for low-income housing: limited and high cost of land, construction of low-income housing that is in accordance with government price limits is located far from cities and workplaces, and there is 
no government inventory for land provision for housing development and land control. Third. The licensing process for PKP development is not transparent and accountable.

\section{Problems in the Housing Infrastructure Sector}

Strategic problems and issues are obtained from the results of an analysis of conditions that occur in housing and settlement areas in West Java Province, as well as based on input from related SKPD through FGD (Forum Goup Discussion). Some of the main problems or strategic issues in each sector of the housing infrastructure sector in the West Java region.

Drinking Water Sector, in the drinking water sector, the problem is that the quality of raw water is low and the quantity of raw water has fluctuated in several places. The distribution of raw water sources is not evenly distributed based on population concentration, so that the distribution of drinking water is not optimal. The institutional performance of Balum applies the principles of good governance so that system management is not optimal, both in PDAMs and in community-managed SPAM management institutions. Limited APBD funding to increase drinking water service coverage. Not all district or city governments have policies and plans for fulfilling drinking water.

The Waste Sector, the waste sector which is a problem is the high number of defecation, from the low level of public knowledge and awareness about PHBS, especially regarding waste, the low commitment of regional heads to the importance of educating people to behave PHBS. The low quality and capacity of local sewage treatment infrastructure, limited regulations on waste water management at the regency / city level, and no specific work unit on wastewater management. The low level of centralized waste services, high environmental pollution due to untreated wastes from IPAL and IPLT and / or leakage of tanks, and limited regulations on wastewater management at the district / city level. Limited funding at the district / city level for the construction of a centralized sewage treatment system. The low commitment of regional heads to waste management.

Drainage Sector. In the drainage sector, it is the inability of water bodies that receive damam to accommodate runoff water. No artificial drainage system is formed. Reduced catchment areas and high infiltration areas. Blockage or no drainage. Not yet optimal handling of flood-prone areas. And the lack of support for the management of the drainage system.

Solid Waste Sector, waste generated by humans, in this case waste, becomes something very urgent, because the behavior of the community in disposing of waste is still done carelessly, there has not been sufficient awareness in terms of waste disposal, let alone to the stage of sorting waste. Inadequate facilities and infrastructure for integrated waste management (at source, TPS, TPA and transportation from upstream to downstream. Solid waste management is oriented from upstream to downstream or known as 3R which is not yet effective and not yet integrated.

\section{Problems in the residential area}

The problem of settlements is a strategic issue obtained from the results of the analysis of the existing conditions of housing and settlement areas in West Java Province, as well as from the input of the relevant SKPD which was carried out through the implementation of the Forum Group Discussion (FGD). Some of the problems that arise in the field of residential areas in West Java Province can be drawn from the essence of the problems, namely: a) PSU services that do not meet standards, have the potential to cause a decrease in the quality of the settlement environment. b) The inability of the community economically to improve the quality of their houses so that there are still people who live in uninhabited houses (rutilahu), c) PSU support is limited because it has not become a government asset because the prerequisites for handover have not been fulfilled,nan cities that are listed in the RTRW / RDTR because in some of the existing problems they do not have the complete documents.

Based on the strategic issues / problems in the residential area sector, the strategy and direction of policy in the area of settlement areas in West Java Province in detail can be seen in the following table (Strategic Issues and Issues, Strategic Plan of the West Java Province Housing and Settlement Office 2019-2023) : 
Table 1.5

Strategy and Policy Direction for Settlement Areas

\begin{tabular}{|c|c|c|c|}
\hline No. & Root of the Problem & Strategy & Policy Direction \\
\hline 1 & $\begin{array}{l}\text { PSU services that do } \\
\text { not comply with } \\
\text { standards, thus } \\
\text { potentially causing a } \\
\text { decrease in the quality } \\
\text { of the housing } \\
\text { environment }\end{array}$ & $\begin{array}{l}\text { Increase the } \\
\text { accessibility of } \\
\text { residential areas to the } \\
\text { minimum standard of } \\
\text { PSU services, and } \\
\text { improve environmental } \\
\text { quality }\end{array}$ & $\begin{array}{l}\text { 1. Integration of housing development with the slum } \\
\text { management program } 1000100 \\
\text { 2. Determination or relocation of residential areas } \\
\text { located on the negative list } \\
\text { 3. Restoration and rejuvenation of the area } \\
\text { 4. Land consolidation } \\
\text { 5. Development of new settlements } \\
\text { 6. Increasing community participation (swadaya) in } \\
\text { maintaining and improving the quality of the } \\
\text { environment in which they live. }\end{array}$ \\
\hline 2 & $\begin{array}{l}\text { The inability of the } \\
\text { community } \\
\text { economically to } \\
\text { improve the quality of } \\
\text { life of their houses, so } \\
\text { that there are still } \\
\text { people who live in } \\
\text { unfit for habitation } \\
\text { (rutilahu) }\end{array}$ & $\begin{array}{l}\text { Increase community } \\
\text { accessibility to } \\
\text { assistance to improve } \\
\text { the quality of } \\
\text { settlements }\end{array}$ & Grant giving to Rutilahu \\
\hline \multirow[t]{4}{*}{3} & \multirow{4}{*}{$\begin{array}{l}\text { PSU support is limited } \\
\text { because it has not } \\
\text { become a government } \\
\text { asset because the } \\
\text { developer has not } \\
\text { surrendered his assets } \\
\text { because the } \\
\text { prerequisites for } \\
\text { handover have not } \\
\text { been fulfilled. }\end{array}$} & \multirow{4}{*}{$\begin{array}{l}\text { Synchronization and } \\
\text { coordination between } \\
\text { steakholde PKP } \\
\text { development related to } \\
\text { the provision of PSU }\end{array}$} & $\begin{array}{l}\text { Assistance to increase the role of local governments in } \\
\text { infrastructure development from housing land for low- } \\
\text { income families so that it is integrated with the main } \\
\text { existing infrastructure }\end{array}$ \\
\hline & & & $\begin{array}{l}\text { Providing subsidized facilities for PSU (Infrastructure, } \\
\text { Facilities, and Utilities) for subsidized housing } \\
\text { developers. }\end{array}$ \\
\hline & & & $\begin{array}{l}\text { Prevention of environmental quality degradation by } \\
\text { monitoring and controlling violations }\end{array}$ \\
\hline & & & $\begin{array}{l}\text { Increasing the role of the community seta (swadaya) in } \\
\text { maintaining and improving the quality of the } \\
\text { environment in which they live }\end{array}$ \\
\hline \multirow[t]{2}{*}{4} & \multirow{2}{*}{$\begin{array}{l}\text { Housing development } \\
\text { is not in line with the } \\
\text { urban development } \\
\text { plans listed in the } \\
\text { RTRW / RDTR } \\
\text { because in some cases } \\
\text { there are no } \\
\text { documents }\end{array}$} & \multirow{2}{*}{$\begin{array}{l}\text { Synchronization of the } \\
\text { housing development } \\
\text { plan stated in the } \\
\text { development plan } \\
\text { document (RPJM) with } \\
\text { the spatial plan (RTRW } \\
\text { / RDTR) }\end{array}$} & $\begin{array}{l}\text { Assistance to Local Governments in efforts to settle and } \\
\text { determine RDTR for each koat / district, to clarify zoning } \\
\text { or space and settlement designation }\end{array}$ \\
\hline & & & $\begin{array}{l}\text { Assistance to local governments in maintaining } \\
\text { consistency in implementing spatial plans (RTRW / } \\
\text { RDTR }\end{array}$ \\
\hline
\end{tabular}

Source: Background Study of West Java Province RPJMD Housing Sector and Settlement Areas 2018-2023

Guidelines for the implementation of alleviating unfit for habitation (Rutilahu) refers to Law No.1 of 2011 concerning Housing and Settlement Areas, in principle it has been explained that everyone has the right to live physically and mentally prosperous, have a place to live and get a good and healthy living environment. which is the basic need of every human being. This is of course very influential on the formation of human character in general, because every existing environment will always have an impact on the pattern of human behavior.

So that slum settlement can be carried out properly, the role of the government must be carried out optimally and optimally. This is due to several programs that prior to the introduction of the law on housing and settlements, still only use programs that only run once. There is no meaningful sustainability, and this will have an impact on infrastructure development and human resource development itself.

The condition of houses is not suitable for habitation in West Java Province, until now it is still quite a lot and almost spread across all districts / cities. In urban areas, houses that are not suitable for habitation are found in urban slum areas, while in rural areas they are scattered mainly in poor rural areas. In reducing the number of houses unfit for habitation in West Java, the West Java Provincial Government has launched the handling of unfit for habitation through a 
program to improve unfit for habitation for districts / cities in West Java with a target of 100,000 units during 2013 - 2018.

Implementation Guidelines - Social Assistance for Improvements to Uninhabitable Houses (Rutilahu)

in West Java 2018 Fiscal Year

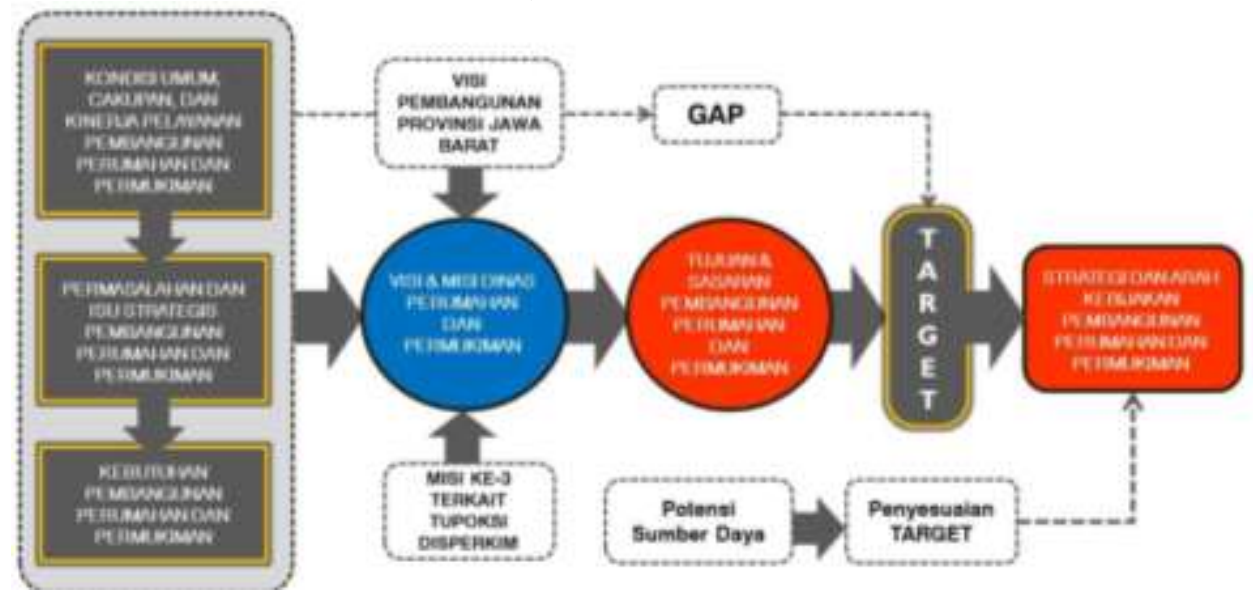

Figure 1.3 Schematic Formulation of Strategy and Policy Direction

Housing and settlement development is basically an effort to meet the basic needs of the people of West Java towards independence and prosperity as aspired by the Regional Government of West Java Province in its vision. The development approach taken must be able to touch human aspects and encourage community empowerment, natural resources, and the environment in West Java to form harmony in development.

The Housing and Settlement Service in carrying out its main tasks and functions of developing West Java uses three aspects which include Divine, Scientific, and Cultural aspects. The approach to these three aspects shows that the development carried out by the Housing and Settlement Service does not only have a clear scientific basis. However, development is also based on considerations of local cultural and religious aspects so that its implementation is more implementedtative.

\section{Authority for Handling Housing and Settlement Development}

Law Number 23 of 2014 concerning Regional Government Article 13 states that the concurrent division of authority between the Central Government, Provincial Regions and City / Regency Regions is based on the principles of accountability, efficiency and externalities, as well as national strategic interests.

The accountability criterion is an approach in the division of a governmental affairs by considering the level of government that handles a part of the affairs, the government that has the authority is the level of government that is closer to the impact of the affairs being handled. Thus the principle of accountability is a guarantee that the implementation of this part of government affairs to the public will be more secure.

The externality criterion is an approach in the division of government affairs by considering the impacts / consequences that ariseright in the implementation of these government affairs. If the impact is local in nature, then the government affairs fall under the authority of the regency / city, if it is regional then it is the authority of the province, and if it is national in nature then the authority of the central government.

The efficiency criterion is an approach in the division of government affairs by considering the availability of resources (personnel, funds and equipment) to obtain the accuracy, certainty and speed of results that must be achieved in the implementation of the affairs division. This means that if a part of the affairs in its handling is certain to be more efficient and effective for the implementation of the Provincial and / or Regency / City regions than if it is handled by the Government, then that part of the affairs is left to the Provincial Region and / or Regency / City Region. On the other hand, if a section of affairs will be more efficient and effective when 
handled by the Government, then that part of the affairs will still be handled by the Government. For this reason, the division of functions must be adjusted by taking into account the scope of the operational area of this part of government affairs. The measure of effectiveness and utility is seen from the amount of benefits felt by the community and the size of the risks that must be faced.

\section{Handling Authority Based on Legislation}

In addition to the poko duties and basic functions of the West Java Province Housing and Settlement Service, it is colored by the umbrella sectoral laws and regulations, such as laws and regulations on spatial planning, solid waste, drinking water, construction and housing services. Based on these laws and regulations, the provincial level handling authority is more focused on the aspects of guidance and facilitation as well as implementation that is inter-district / municipal or has regional impacts.

Kewenangan Penanganan Berdasarkan Undang-Undang Nomor 1 Tahun 2011 tentang Perumahan dan Kawasan Permukiman. Seperti halnya Pemerintah Pusat, Pemerintah provinsi juga memiliki tugas dan wewenang dalam melaksanakan pembinaan penyelenggaraan perumahan dan kawasan permukiman.

The provincial government in carrying out the guidance has the following duties: a) To formulate and determine policies and strategies at the provincial level in the field of housing and settlement areas based on national policies. b) Formulating and stipulating provincial policies concerning the utilization and utilization of technological engineering results in the housing and settlement areas based on the national policy. c) Formulating and stipulating policies for the provision of Kasiba and Lisiba across districts / cities. d) Oversee the implementation of national policies and strategies at the provincial level in the field of housing and settlement areas. e) Carrying out operationalization functions and coordinating the implementation of provincial policies on the provision of houses, housing, settlements, residential areas and residential areas. f) Compiling plans for the development and development of housing and settlement areas across districts / cities. g) Facilitating the management of infrastructure, facilities and public utilities for housing and settlement areas at the provincial level. h) Allocating and / or development costs to support the realization of low-income housing. i) Facilitating the provision of housing and settlement areas for the community, especially for low-income families. j) Facilitating the implementation of policies and strategies at the provincial level especially for MBR. j) Facilitating the implementation of policies and strategies at the provincial level especially for MBR. j) Facilitating the implementation of policies and strategies at the provincial level

In order to carry out these tasks, the provincial government has the authority to carry out fostering implementation of housing and settlement areas. The provincial government in carrying out guidance has the authority to: a. Compile and provide a database of housing and settlement areas at the provincial level. b) Compiling and perfecting legislation on housing and settlement areas at the provincial level. c) Empowering stakeholders in the housing and settlement areas at the provincial level. d) Coordinating, synchronizing and disseminating statutory regulations as well as policies and strategies for implementing housing and settlement areas at the provincial level in the context of realizing legal security and certainty and legal protection in living. e) Coordinating the utilization of environmentally friendly technology and design as well as the use of the building material industry which strengthens domestic resources and local wisdom. f) Coordinating the supervision and control of the implementation of laws and regulations, policies, strategies, and programs in the housing and settlement areas at the provincial level. g) Evaluating statutory regulations as well as policies and strategies for housing and settlement areas at the provincial level. h) Facilitating the improvement of the quality of slum housing and slum settlements at the provincial level. i) Coordinating the provision or provision of land to build housing and settlements for MBR at the provincial level. j) Establish policies and strategies for provincial areas in the implementation of housing and settlement areas based on national policies. k) Facilitating cooperation at the provincial level between the provincial government and legal entities in the management of housing and settlement areas.

In Law No.1 of 2011 concerning Housing and Settlement Areas, it is mandated that each Province and Regency / City have the task of compiling a Housing and Settlement Area 
Development and Development Plan (RP3KP) in its territory. It is hoped that the RP3KP document can become a legal umbrella in planning for the development and development of housing and settlement areas.

The implementation of settlement and housing development as outlined in the 2013-2018 strategic plan carries out the mission as stipulated in the regional development planning documents, especially the 2013-2018 RPJMD and also spatial plans such as the RTRW of West Java Province. However, all of this is limited by the authority and institutional aspects of the Housing and Settlement Service with the main tasks and functions that have been determined through Governor Regulation No.71 of 2013 concerning Amendments to Governor Regulation No. 46 of 2010 concerning the main tasks, functions, details of unit tasks and work procedures for the housing and settlement office of West Java Province. Therefore, in an effort to achieve the predetermined performance indicator targets, the Provincial Government, especially the Housing and Settlement Service, is only one of the stakeholders.

The authority of the Provincial Government regarding Housing Affairs in Law Number 23 of 2014 concerning Regional Government. Housing and residential areas are one of the mandatory government affairs which are in the division of concurrent affairs between the Central and Regional Governments, there are criteria for Government Affairs which fall under the authority of the province, namely: a) Government affairs which are located across districts/cities, b) Government Affairs whose users cross regency/municipal regions, c) Government affairs which benefit or negatively impact cross regency/municipal regions and d) Government affairs whose use of resources is more efficient when carried out by Provincial Regions.

The authority of the Provincial Government in Provision of Housing related to Law Number 20 of 2011 concerning Flats. Flat is a multi-storey building built in an environment which is divided into functional structured parts, both in horizontal and vertical directions and are units that each can be owned and used separately, especially for a furnished dwelling. with common parts, common objects, and common lands. The management of flats is the activity of planning, building, controlling and utilizing, managing, maintaining and maintaining, controlling, institutional, funding and financing systems, as well as community roles which are carried out in a systematic, integrated, sustainable and responsible manner.

The authority and role of the provincial government in relation to the management of flats include: a) Formulating policies and strategies in the field of flats at the provincial level based on national policies and strategies; b) Compiling plans and programs for the development and development of flats at the provincial level based on national planning; c) Synchronizing and disseminating statutory regulations as well as policies and strategies for the management of flat at the provincial level; d) Carry out the function of operationalizing the policy of providing flat and developing the apartment's residential environment as part of the residential area at the provincial level; e) Empowering stakeholders in the field of flats at the provincial level; f) Implementing minimum service standards for flat; g) Carry out coordination and facilitation of the preparation and provision of databases for flats in districts / cities in the province; $h$ ) Allocating funds and / or development costs to support the realization of public flats, special flats and state flats; i) Facilitating the provision of flats for the community, especially for MBR; j) Facilitating the provision of public infrastructure, facilities and utilities for flats provided for MBR; k) Implementing provincial policies concerning the utilization and utilization of technology engineering results in the field of flats guided by the national policy; l) To reserve or acquire land for public flats, special flats, and state flats in accordance with the designation of the location for the construction of flats.

This Government Regulation is a more technical explanation of Law No. 1. Year on Housing and Settlement Areas. The implementation of housing and residential areas is aimed at: a) creating order in the administration of housing and residential areas; b) provide legal certainty for all stakeholders in carrying out their duties as well as their rights and responsibilities in the administration of housing and residential areas; c) realizing justice for all stakeholders, especially for MBiR in implementing housing and residential areas.

Handling Authority Based on Law Number 18 Year 2008 concerning Waste Management. The division of authority of the Central Government, Provincial Governments and Regency / City 
Governments related to solid waste management is regulated in Law Number 18 of 2008 concerning Solid Waste Management. The table shows the authority of each party

Handling Authority Based on Government Regulation Number 16 of 2005 concerning Development of Drinking Water Supply Systems. The development of drinking water is the task of the Central Government, Provincial Governments and District / City Governments. Therefore, it is necessary to share roles and finance in order to accelerate the improvement of drinking water services. The description of the division of authority for drinking water services is in accordance with Government Regulation Number 16 of 2005 concerning the Development of a Drinking Water Supply System.

\section{CONCLUSION}

The important role of the government in efforts to alleviate and create livable homes for communities in the province of West Java refers to the foundation for handling housing and slum settlements as the national target outlined in the 2015-2019 National Medium Term Development Plan (RPJMN). The government's policy towards alleviating unfit for habitation has been part of the planning starting in 2018 as in the 2018-2023 RPJMD of West Java Province. Rutilahu in principle, as in the 2018-2023 RPJMD, is a house that does not meet the building safety requirements and the minimum adequacy of the building area and the health of its occupants. During the 2018-2023 RPJMD period, repairs are planned for 100,000 (one thousand units) routinely with 80 details. 000 units of rural route categories in 18 districts and as many as 20,000 units for urban route categories in 9 cities. The West Java Provincial Government has renovated 109,293 out of 285,000 unfit for habitation by 2018.37 Main Programs and activities of West Java Province (SK. Governor of West Java No. 500 / Kep. / 66-Org / 2014) in the Assistant Government, Law and human rights, routine has become one of the programs launched, one of which is by carrying out rehabilitation of 100,000 poor people's homes.

Obstacles and efforts made in the process of alleviating unfit for housing and settlements in the province of West Java are: First, House prices are not affordable for low-income groups (MBR) and under MBR. Second, the issue of providing land for low-income housing, limited and expensive land prices, building houses for low-income housing that are in accordance with government price limits are located far from cities and workplaces, and there is no government inventory of land for housing development and controlling land. Third, the licensing stages for PKP development are not transparent and accountable. Another problem that arises is in the field of residential infrastructure, namely in the sector of drinking water, waste, drainage and solid waste.

\section{REFERENCES}

Badan Pusat Statistik, Kompilasi Indikator Statistik Terkini Provinsi Jawa Barat November 2019 Bappeda Jabar Humas, http://bappeda.jabarprov.go.id/pemprov-jabar-renovasi-109-293-dari285-000-rumah-tak-layak-huni-hingga-2018/

Dewi Putranto Riau, Peranan Pemerintah Daerah Dalam Penyelenggaraan Perumahan,

Didin Wahyudin, Impelentasi Kebijakan dalam Mewujudkan Program Perbaikan Rumah Tidak Layak Huni di Kecamatan Arcamanik Kota Bandung, studi Peraturan Gubernur Nomor 82 Tahun 2014 tentang Belanja Hibah dan Bantuan Sosial

Direktorat Jendral Cipta Karya, Kementerian Pekerjaan Umum dan Perumahan Rakyat, Bersama Program KOTAKU “Kita Tuntaskan Kumuh".

Dokumen Rancana Strategis Dinas Perumahan dan Permukiman Provinsi Jawa Barat Tahun 2018-2023

Geographical Situation, https://jabarprov.go.id/root/dalamangka/dda2003Geogra fi.pdf https://laci.bps.go.id/s/xLbiD08ZU1jTIlb\#pdfviewer https://laci.bps.go.id/s/xLbiD08ZU1jTIlb\#pdfviewer, tentang perkembangan penduduk Jawa Barat sejak 1971 - 2019). 
Human Settelment and Environmental Health, Statistik Lingkungan Hiidup Indonesia Environmental Statistics of Indonesia 2015. Hm. 199

Humas Bappeda Jabar, Pemprov Jabar Usul UU terkait Perumahan Direvisi .http://bappeda. jabarprov.go.id/pemprov-jabar-usul-uu-terkait-perumahan-direvisi/

Impelentasi Kebijakan dalam Mewujudkan Program Perbaikan Rumah Tidak Layak Huni di Kecamatan Arcamanik Kota Bandung, (Studi Peraturan Gubernur Nomor 82 Tahun 2014 tentang Belanja Hibah dan Bantuan Sosial).

Josef. Riwu Kaho. (2001). Prospek Otonomi Daerah di Negara Republik Indonesia. Jakarta, Penerbit Raja Grafindo Persada.

Kaloh. (2007) Mencari Bentuk Otonomi Daerah: Suatu Solusi dalam Menjawab Kebutuhan Lokal dan Tantangan Global. Jakarta, Penerbit Rineka Cipta.

Kementerian Pekerjaan Umum dan Perumahan Rakyat Direktorat Jendral Cipta Karya, Kotaku (Kota Tanpa Kumuh) National Slum Upgrading Program (NUSP-2) Neighbordhood Upgrading and Shelter Projcet - Phase 2 (NUSP - 2)

Kementerian Perumahan Rakyat Republik Indonesia, Peran Pemerintah dalam Pembangunan Perumahan Swadaya. Kepala Biro Perencanaan dan Anggaran, Jakarta, 13 Desember 2011.

Keputusan Menteri Permukiman dan Prasarana Wilayah Nomor : 403/ KPTS/M/2002 tentang Pedoman Teknis Pembangunan Rumah Sederhana Sehat (RS Sehat);

Lubis, Ibrahim. (1985) Pengendalian dan Pengawasan Proyek dalam Manajemen. Jakarta, Penerbit Ghalia Indonesia.

Mashoed (2004) Pemberdayaan Masyarakat Miskin: Membuka Kawasam Terisolasi. Surabaya, Penerbit Papyrus.

Nugroho, Riant, (2012) Public Police, Jakarta: PT.Elex Media Komputindo

Pedoman Pelaksanaan - Bantuan Sosial Perbaikan Rumah Tidak Layak Huni (Rutilahu) di Jawa Barat Tahun Anggaran 2018.

Peraturan Daerah Provinsi Jawa Barat Nomor 17 Tahun 2017, tentang Anggaran Pendapatan dan Belanja Daerah Provinsi Jawa barat Tahun Anggaran 2018 Lembaran Daerah Nomor 17 Tanggal 29 Desember 2017;

Peraturan Gubernur Jawa Barat No. 4 Tahun 2017, tentang Perubahan atas Peraturan Gubernur Jawa Barat Nomor 34 Tahun 2016 tentang Tata Cara Pengganggaran, Pelaksanaan, Penatausahaan, Pertanggungjawaban, Pelaporan serta Monitoring dan Evaluasi Belanja Hibah dan Belanja Bantuan Sosial Bersumber dari Anggaran Pendapatan dan Belanja Daerah Provinsi Jawa Barat.

Peraturan Gubernur Jawa Barat Nomor 46 Tahun 2015 Tentang Pedoman Program Perbaikan Rumah Tidak Layak Huni.

Peraturan Gubernur Jawa Barat Nomor 91 Tahun 2017, tentang Penjabaran Anggaran Pendapatan dan Belanja Daerah Tahun Provinsi Jawa Barat Tahun Anggaran 2018 Berita Daerah Nomor 91 tanggal 29 Desember 2017;

Peraturan Menteri Kesehatan RI Nomor : 1077/ Menkes/ PER/V/2011 tentang Pedoman Penyehatan Udara dalam Ruang Rumah;

Peraturan Menteri Pekerjaan umum Nomor 29/PRT/M/2006 Tahun 2006 tentang Pedoman Persyaratan Teknis Bangunan Gedung;

Peraturan Pemerintah Nomor 36 Tahun 2005 tentang Peraturan Pelaksanaan Undang-Undang Nomor 28 Tahun 2002 tentang Bangunan Gedung (Lembaran Negara Republik Indonesia Tahun 2005 Nomor 83, Tambahan Lembaran Negara Republik Indonesia Nomor 4532);

Permasalahan dan Isu Strategis, Rencana Strategis Dinas Perumahan dan Permukiman Provinsi Jawa Barat Tahun 2019-2023.

Copyright (C) 2019, JCIC - Journal of CIC, Social Consultant and Research Institute 70 
Permenpera RI No. 22/PERMEN/M/2008 tentang Standar Pelayanan Minimal (SPM) Bidang Perumahan Rakyat Daerah Provinsi dan Daerah Kabupaten/Kota;

Rancangan Akhir Rencana Pembangunan Janka Menengah Daerah (RPJMD) Provinsi Jawa Barat Tahun 2018-2023

Rizki Pryo dkk, Peran Pemerintah Dalam Menciptakan Perumahan Layak Huni (Studi pada Dinas Pekerjaan Umum Cipta Karya dan Tataruang, Kabupaten Sidoarjo), Jurnal Administrasi Publik.

Siagian, P, Sondang. Administrasi Pembangunan Konsep, Dimensi, dan Strateginya. Jakarta, Bumi Aksara

Silas. J (1996), Syaiful. A (2002). Kampung Surabaya Menuju Metropolitan Permukiman Marjinal amat Liar.

Siti Aminah, Kebijakan Pemenuhan Kebutuhan Perumahan dan Kawasan Permukiman (PKP) di Provinsi Papua. Jurnal Kajian EKonomi dan Studi Pembangunan. Vol II No. 2 Agustus 2018

Soekanto, Soerjono dan Sri Mahmudji, (2003) Penelitian Hukum Normatif Suatu Tinjauan Singkat, PT. Raja GrafindoPersada, Jakarta

Standar Nasional Indonesia (SNI) yang terkait dengan perencanaan teknis bangunan rumah.

Strategi dan Arah Kebijakan, Rancangan Akhir Rencana Pembangunan Janka Menengah Daerah (RPJMD) Provinsi Jawa Barat Tahun 2018-2023, Hlm. 61

Suharto, Edi, (2008)Analisis Kebijakan Publik Panduan Praktis Mengkaji Masalah dan Kebijakan Sosial, Bandung: IKAPI

Sumber: Background Study RPJMD Provinsi Jawa Barat Sektor Perumahan dan Kawasan Permukiman Tahun 2018- 2023

Undang-Undang Nomor 1 Tahun 2011 tentang Perumahan Dan Kawasan Pemukiman

Undang-Undang Nomor 1 Tahun 2011 tentang Perumahan dan Kawasan Pemukiman (Lembaran Negara Republik Indonesia Tahun 2011 Nomor 7, Tambahan Lembaran Negara Republik Indonesia Nomor 5188);

Undang-Undang Nomor 28 Tahun 2002 tentang Bangunan Gedung (Lembaran Negara Republik Indonesia Tahun 2002 Nomor 134; Tambahan Lembaran Negara Republik Indonesia Nomor 4247);

Undang-Undang Nomor 32 tahun 2004 tentang Pemerintahan Daerah.

Wahab, Solichin Abdul, (2004) Analisis Kebijaksanaan, Jakarta: Bumi Aksara 